\title{
Implementation of Qanun Number 11 of 2018 concerning Islamic Financial Institutions at State-Owned Banks in Lhokseumawe City
}

\author{
Nurul Kamaly ${ }^{1}$, M. Irvanni Bahri ${ }^{2}$
}

\begin{abstract}
This study will look into how regional regulation in Aceh is applied, specifically Qanun No.11 Year 2018 in terms of shari'a financial affiliate. This study is conducted at Bank Negara Indonesia (BNI), Bank Tabungan Negara (BTN), and Bank Mandiri, all of which are state-owned enterprises (BUMN) in the city of Lhokseumawe. This study's goal is to examine Qanun adoption by the aforementioned conventional banks, as well as the forecasts that those affiliates face in the process of implementing the Qanun of shari'a financial affiliate. This study is qualitative in nature since it completely and comprehensively explains the phenomena under investigation. Data was gathered by observation, interview, and documentation. The interactive model of inquiry was used to assess all of the data collected. According to the findings of this study, traditional banks have been devoted to Qanun implementation since 2019, starting with survey management and piloting public education linked to shari'a financial affiliate qanun. Traditional banks are currently in a 'ongoing' phase when it comes to the conversion of traditional accounts to shari'a accounts. Furthermore, asset asymmetry and employment management efforts have been ongoing. Nonetheless, there were a slew of roadblocks in the actual world. Among these were the growing lines of everyday customers wishing to convert their accounts to shari'a, the frequent occurrence of issues in the shari'a IT system, and the lack of clarity on the status of employees converting to shari'a. However, by 2021, every conventional bank in Aceh will have to be converted to shari'a law in accordance with Qanun No.11 of 2018.
\end{abstract}

Keywords: Implementation, Conversion, Conventional Bank, Syari'ah Bank

\section{Introduction}

Islamic banking began to be recognized for its existence with the issuance of Law Number 7 of 1992 concerning Banking which uses the notion of profit sharing. Since then, Bank Muamalat, the first Islamic bank in Indonesia, has been operating. When Law Number 10 of 1998 was passed as an amendment to Law Number 7 of 1992, the existence of Islamic banking became stronger. Commercial banks and rural credit banks operate conventionally and/or based on sharia principles in accordance with changes to the law. Then, in 2008, President Susilo Bambang Yudhoyono signed Law No. 21 concerning Sharia Banking which is still valid today.

\footnotetext{
${ }^{1}$ Universitas Malikussaleh, kamalynurul26@gmail.com

${ }^{2}$ Sekolah Tinggi Agama Islam Aceh Tamiang, m.irvannibahri@gmail.com
} 
Users of banking services in Indonesia welcome the growth of the sharia banking business, especially in areas where the majority of the population is Muslim, such as Aceh. Not only that, the people of Aceh place great emphasis on Islamic principles. These Islamic values are practiced in many aspects of life, including economic development. Furthermore, Aceh has a number of Qanuns related to the implementation of Islamic Sharia, including Qanun Number 9 of 2014 concerning the Establishment of Banking in Aceh.

Aceh is considered as one of the most outstanding provinces in Indonesia for the application of Islamic law in daily life. Not surprisingly, Islamic ideas are used to ratify various Regional Regulations (Perda) or Qanun. The government of Bumi Serambi Mekkah has released a Qanun on Sharia Financial Institutions which has become a hot topic of discussion (LKS). The regulation requires all financial institutions in Aceh to adapt and switch to the sharia system as soon as possible, including the conversion of traditional banks. Qanun is also not formed instantaneously, but through the screening of people's ambitions. All variables are considered when discussing LKS qanuns, particularly financial institutions such as banks.

There were pros and cons, but in the end everyone decided that the qanun should be implemented in Aceh. These regulations apply to banks and nontraditional financial entities. This regulation applies to all financial institutions in Aceh, as well as all people in Aceh, the Aceh Provincial Government, and districts/cities in Aceh, as well as financial institutions headquartered in Aceh. On December 31, 2018, Aceh Qanun Number 11 of 2018 was adopted which contains Sharia Financial Institutions (LKS), a significant step forward in the development of the sharia economy in Aceh. Aceh's superiority in carrying out the implementation of Islamic law goes hand in hand with this. The establishment of the qanun for Islamic financial institutions (LKS) in Aceh was based on three factors: philosophy, sociology, and legality.

Table 1. Conventional Bank Data in Aceh

\begin{tabular}{|l|l|c|r|r|r|}
\hline No. & \multicolumn{1}{|c|}{ Nama Bank } & $\begin{array}{c}\text { Jumlah } \\
(\text { KC) }\end{array}$ & \multicolumn{1}{|c|}{ Aset } & \multicolumn{1}{|c|}{ Kredit } & \multicolumn{1}{c|}{$\begin{array}{c}\text { Dana Pihak } \\
\text { Ketiga }\end{array}$} \\
\hline 1 & Bank Mandiri & 3 & 3.840 .884 & 3.801 .893 & 2.800 .825 \\
\hline 2 & $\begin{array}{l}\text { Bank Mandiri } \\
\text { Taspen }\end{array}$ & 1 & 431.862 & 426.103 & 65.452 \\
\hline 3 & BRI & 11 & 13.529 .776 & 13.237 .147 & 8.496 .838 \\
\hline
\end{tabular}


Implementation of Qanun Number 11 of 2018 concerning Islamic Financial

\begin{tabular}{|l|l|r|r|r|r|}
\hline 4 & BNI & 6 & 8.128 .874 & 2.063 .051 & 2.904 .797 \\
\hline 5 & BTPN & 2 & 857.365 & 794.158 & 147.391 \\
\hline 6 & BCA & 2 & 726.683 & 62.879 & 724.640 \\
\hline 7 & Bukopin & 1 & 465.110 & 361.063 & 384.220 \\
\hline 8 & Bank Panin & 1 & 196.342 & 52.308 & 196.727 \\
\hline 9 & $\begin{array}{l}\text { Bank Danamon } \\
\text { Indonesia }\end{array}$ & 2 & 980.510 & 83.852 & 423.309 \\
\hline 10 & $\begin{array}{l}\text { Bank Maybank } \\
\text { Indonesia }\end{array}$ & 1 & 105.850 & 24.758 & 115.674 \\
\hline 11 & BTN & 1 & 1.448 .512 & 1.433 .353 & 276.708 \\
\hline 12 & Bank CIMB Niaga & 1 & 153.027 & 2.395 & 154.537 \\
\hline \multicolumn{2}{|c|}{ Total } & $\mathbf{3 2}$ & $\mathbf{3 0 . 8 6 4 . 7 9 5}$ & $\mathbf{2 2 . 3 4 2 . 9 6 0}$ & $\mathbf{1 6 . 6 9 1 . 1 1 8}$ \\
\hline
\end{tabular}

Source: OJK data March 2019

The philosophy of Qanun is based on the Qur'an and hadith, which have become beliefs and guidelines for the Acehnese people in applying Islamic law. While one of them is sociologically related to achieving a just and prosperous Aceh economy based on Islamic law, which requires the use of Islamic financial institutions. In accordance with Law Number 11 of 2006 concerning the Government of Aceh, Aceh is given the authority by the government to make and control the implementation of Islamic law.

In this study, researchers will look at the banking industry, namely the National Bank Association which is included in HIMBARA. The Association of State Banks or State-Owned Enterprises (BUMN) includes 4 (four) conventional banks: Bank Negara Indonesia (BNI), Bank Rakyat Indonesia (BRI), Bank Mandiri, and Bank Tabungan Negara (BTN). For the initial stage of implementing the Qanun on Sharia Financial Institutions (LKS), the Aceh government believes that by 2021 all banks have switched to Islamic banks, followed by other financial institutions until all of them are $100 \%$ Sharia, which is expected to be realized. in 2023 or 2024.

A number of banks have started using this Qanun in 2020 and are in the process of converting to Sharia. To be successful, the Acehnese themselves must play an active role in the implementation of this Qanun. The people of Aceh must be ready to make full use of Islamic financial goods. In addition to generating economic growth, the positive impact can also create jobs for the people of Aceh. As a result, it is possible that the Qanun on Sharia Financial Institutions (LKS) can help Aceh's economy which is lagging behind other provinces. Based on the above discussion, the researcher wants to discuss research in the city of Lhokseumawe with the topic of implementing Qanun 
IHTIYATH Jurnal Manajemen Keuangan Syariah

Vol. 5 No. 2, Desember 2021

Number 11 of 2018 concerning Islamic Financial Institutions in Conventional Banking State-Owned Enterprises (BUMN).

\section{Banking Conversion}

The Big Indonesian Dictionary (KBBI) defines conversion as a change from one knowledge system to another, as well as a change from one form to another. Conventional banks can adjust their business activities to become Islamic banks, in accordance with Article 2 paragraph (1). The authority of Bank Indonesia to regulate conversion is limited to commercial business entities as referred to in PBI No. 8/3/PBI/2006, and does not include product conversions. Banks must resolve objections from customers who use bank products within one year of receipt (Umam and Antoni, 2015). Technically, the method of converting a conventional bank to an Islamic bank is not stated in Law Number 10 of 1998 concerning Amendments to Law Number 7 of 1992 concerning Banking.

Article 2 PBI No. 8/3/PBI/2006 which basically states that a bank can only change its business activities into a bank carrying out business activities based on sharia principles with the permission of the Governor of Bank Indonesia, and that the plan must be included in the bank's business plan, is technically regulated. PBI No.8/3/PBI/2006 as previously mentioned, has now been canceled by PBI No.11/15/PBI/2009 regarding the adjustment of commercial activities of traditional banks to sharia.

Conventional banks can adjust their business activities to become Islamic banks, in accordance with Article 2 paragraph (1). Then in paragraph (2) it is emphasized that Conventional Commercial Banks can switch to Islamic Commercial Banks, and BPRs can switch to Sharia People's Financing Banks (Umam and Antoni, 2015). A traditional bank that wants to change its business activities to a sharia bank must (1) change the articles of association, (2) meet the capital requirements, (3) change the requirements for the board of directors and commissioners, (4) establish a Sharia Supervisory Board (DPS), and (5) presenting initial finance. 


\section{Conventional Banks and Islamic Banks}

Conventional banks are banks that were established before Nank Syariah in Indonesia and have facilities that are widely available in the country. Conventional, according to the Big Indonesian Dictionary, means "according to what has become a habit". From the description above, it can be said that a conventional bank is a bank that carries out its commercial activities using existing interest techniques and has been used by banks in the past to generate profits from their operations. In this situation, the Indonesian people are very experienced in interest-based financing strategies.

As a financial intermediary institution, the bank is one of the financial institutions that play an important role in the economy of a country. Bank is defined as a business entity that collects funds from the public in the form of savings and distributes them to the public in the form of credit or other forms in order to improve the standard of living of the community in Article 1 paragraph (2). Law Number 10 of 1998 concerning Amendments to Law Number 7 of 1992 concerning Banking. Islamic banks, on the other hand, are financial institutions that adhere to an Islamic economic system. "Islamic economy, according to its creators and supporters, is built on or at least spiced up by religious concepts, directed towards the world and the hereafter," Farida (2011).

Sharia principles are defined as follows in Article 1 number 13 of Law Number 10 of 1998 concerning Banking: "Sharia principles are the rules of agreements based on Islamic law between banks and other parties to deposit funds and or finance business activities, or other stated activities. according to sharia, such as financing based on the principle of profit sharing (mudharabah), financing based on equity participation (musyarakah), the principle of buying and selling goods for profit (mudharabah), or financing of capital goods based on principles. pure lea (mudharabah) (ijarah) "Or by another party transfers ownership of the goods rented from the bank (hijarah wa iqtina)."

Meanwhile, Article 1 paragraph 12 of Law Number 21 of 2008 concerning Sharia Banking stipulates that what is meant by sharia principles are the principles of Islamic law in banking activities based on fatwas issued by institutions authorized to issue fatwas in the field of sharia. Sharia bank according to the above definition is a business entity that carries out its 
IHTIYATH Jurnal Manajemen Keuangan Syariah

Vol. 5 No. 2, Desember 2021

intermediary role in accordance with sharia principles, or in other words a bank which in collecting and distributing funds provides rewards in accordance with sharia principles.

\section{Similarities and Differences between Conventional and Islamic Banks}

Technical acceptance of money, transfer channels, computer technology used, and general requirements for obtaining financing, such as ID cards, NPWP, proposals, financial statements, and so on, are all similarities between conventional banks and Islamic banks. Legal aspects, organizational structure, companies being financed, and work environment are the main differentiators between the two. Some of the differences between Islamic and conventional banks according to Ismail (2013), include:

Table 1. Differences in Conventional Banking and Islamic Banking

\begin{tabular}{l|l}
\hline \multicolumn{1}{c|}{ Islamic Bank } & \multicolumn{1}{|c}{ Conventional Bank } \\
\hline $\begin{array}{l}\text { Investment, only for halal and profitable } \\
\text { projects and products. }\end{array}$ & $\begin{array}{l}\text { Investment does not consider halal or haram } \\
\text { as long as the project being financed is } \\
\text { profitable. }\end{array}$ \\
\hline $\begin{array}{l}\text { Returns that are paid and/or received come } \\
\text { from profit sharing or other income based } \\
\text { on sharia principles. }\end{array}$ & $\begin{array}{l}\text { Goods returns that are paid to customers who } \\
\text { deposit funds and returns received from } \\
\text { customers who use funds in the form of } \\
\text { interest. }\end{array}$ \\
\hline $\begin{array}{l}\text { The agreement is made in the form of a } \\
\text { contract in accordance with Islamic law. }\end{array}$ & Agreements are made using positive law. \\
$\begin{array}{l}\text { The orientation of financing, not only for } \\
\text { profit but also falah oriented, that is oriented } \\
\text { to the welfare of the community. }\end{array}$ & $\begin{array}{l}\text { Financing orientation, to get a profit on loaned } \\
\text { funds. }\end{array}$ \\
\hline $\begin{array}{l}\text { The relationship between the bank and the } \\
\text { customer is a partner. }\end{array}$ & $\begin{array}{l}\text { The relationship between bank and customer } \\
\text { is creditor and debtor. }\end{array}$ \\
\hline $\begin{array}{l}\text { The supervisory board consists of BI, } \\
\text { Bapepam, Commissioners, and the Sharia } \\
\text { Supervisory Board (DPS). }\end{array}$ & $\begin{array}{l}\text { The supervisory board consists of BI, } \\
\text { Bapepam, and commissioners. }\end{array}$ \\
\hline $\begin{array}{l}\text { Dispute resolution is sought to be resolved } \\
\text { amicably between the bank and the } \\
\text { customer, through the religious court. }\end{array}$ & $\begin{array}{l}\text { Dispute Resolution Through the local district } \\
\text { court. }\end{array}$ \\
\hline
\end{tabular}

\section{Weaknesses of Islamic Banks}

In Farida (2011), John L. Eposito criticizes Islamic Economics, claiming that: "Overall, Islamic Economics is better at explaining what Islamic Economics is not than determining what makes Islamic Economics unique. It is also better at revealing flaws in other systems than shows (that Islamic Economics as a whole) is superior." 
According to Sulistiyawan (2015), Islamic banks have six weaknesses that cause at least some people to become customers of Islamic banks. (1) Islamic bank advertisements are not wide enough for diverse communities, (2) few offices, (3) ordinary people, (4) small number of automated teller machines (ATMs), (5) products not yet known to the public, and (6 ) lack of facilities is one of the drawbacks. Furthermore, Islamic banks have the following weaknesses:

a. The Islamic Bank Network is still in its infancy.

b. Human resources in Islamic banks are still scarce.

c. There is still a lack of public knowledge about Islamic banking.

d. Project appraisal errors have a greater impact than those made by traditional banks

\section{Policy Implementation}

The verb "to carry out" is the source of the term "implementation", which is a translation of the word "implementation". The term "implement" comes from the Latin "implementum," which is the root of the words "impere" and "plere," according to Webster's Dictionary (1979). The verb "implere" means "to fill"; "to fill in" which means "to fill in complete; complete," but "plere" means "to fill" (Tachan, 2008). So etymologically implementation can be interpreted as an activity to complete or implement a public policy that has been determined/approved with the use of facilities (tools) to achieve policy objectives, while the implementation of public policy can be interpreted as an activity to complete or implement a public policy that has been determined/approved by use of facilities (tools) (Tachan, 2008).

"Policy implementation" is defined by Akib (2010) as "an activity that occurs after the issuance of valid policy directions and includes efforts to control inputs to achieve outputs or outcomes for society." "The characteristics of policy implementation are the policies that have been taken and implemented by administrative bodies that mobilize financial and human resources," according to William Dunn (2000).

Solichin (2001) quotes Lallham "At least three important components make up public policy: (1) aims to be achieved, (2) specific goals, and (3) means to achieve those goals. Implementation, which is often translated into programs of 
action. and initiative, is a term used to describe how to achieve this goal. These activities usually contain information such as who implements it, the amount of funds and sources, who is the target group, how the program or project is managed, and how the success or performance of the program is measured. In short, policy implementation is a process where a policy achieves its objectives.

In principle, policy implementation is nothing more than a means for a policy to achieve its goals. There are two ways to implement public policies: direct implementation in the form of programs or formulation of derivative policies or derivatives of these public policies" (Nugroho, 2003). "The aim of policy is principally to interfere," wrote Nugroho (2003). Consequently, policy execution is an act of intervention in itself."

\section{Factors Supporting Policy Implementation}

The step between policy making and the effect the policy will have on the target population is known as policy implementation. According to George $\mathrm{C}$ Edward, effective policy implementation requires attention to four main issues: resources (resources), communication (communication), attitudes (dispositions or attitudes), and bureaucratic structure (bureaucratic structure). The four elements are described as follows:

1. Resources.

Because human resources are a very important aspect in program implementation, limited resources both in quality and quantity will result in the program not running smoothly.

2. Communication.

Effective communication requires understanding by the authorities, as well as consistency in the objectives to be communicated, so that policy implementers and the target community are aware of and understand policy objectives in a precise, firm, and accurate manner.

3. Practice Attitude

The attitude of the implementor is one of the elements that affect the effectiveness of policy implementation. The attitude and dedication of the implementers to the policies or programs being implemented, in particular.

4. Bureaucratic Structure 
The nature, rules, and patterns of relationships that occur regularly in the executive body that have a relationship, both potential and real, in carrying out policies are referred to as bureaucratic structures.

"Environmental elements are very important in the program implementation process," according to Van Meter and Van Horn, in addition to the four criteria. This component can be economic, political, and social conditions, such as institutional collaboration and political motivation for the program. Economic factors refer to financial support for program implementation, while social factors refer to one of the conditions under which the implementation process can be carried out properly and effectively or not, based on community responses and social conditions, whether they support or reject. a planned program. As a result, environmental influences can hinder and assist the implementation of a program.

\section{Research Methods}

This research is descriptive qualitative. This study aims to find, explain, review, analyze all documents, references, facts, theories, library research with qualitative methods, because this research is based on written data, as part of the data. qualitative in the form of words, sentences, and charts, (Sugiyono, 2017)

The data sources in this study are secondary data sources, namely reports, articles, and laws and regulations related to regulations governing Islamic banking in Indonesia, namely Law no. 7 of 1992, then Law No. 10 of 1998, Law no. 21 of 2008, and Aceh Qanun No. 11 of 2018, then analyzed it using inductive thinking, because the source of the data has been processed or documented as well as observing the conversion process of conventional banking to sharia and analyzing the obstacles that arise in the process of implementing this Qanun in Islamic financial institutions in conventional banking, which is one of the efforts that Researchers will conduct research as the main instrument in collecting data from the research focus by collecting data and interviews with the heads or representatives of each state-owned bank as well as methods of implementing Islamic banks in the city of Lhokseumawe. 


\section{Research Results And Discussion}

In 2019, the strategy used to implement Qanun Number 11 of 2018 concerning Islamic Financial Institutions has begun to be implemented. The initial plan for conventional banking in the city of Lhokseumawe was to conduct an initial survey of customers and conventional banking workers to find out whether they are ready and agree with the presence of the Qanun on Islamic Financial Institutions. The readiness of the apparatus refers to the readiness of actors implementing public policies to provide services based on the level of expertise of each apparatus in their respective disciplines. Employees and customers have completed a survey on the conversion of traditional banking to Islamic banking as part of the initial outreach step.

\section{Stage 1 Socialization}

For the socialization of conventional banking in Lhokseumawe City, they held training for employees of each bank to participate in the socialization of Qanun Number 11 of 2018 concerning Islamic Financial Institutions and customers also filled out a website survey whose scope was an area of Lhokseumawe City. The initial socialization stage for employees and customers has filled out a survey, as conveyed by Mr. Yason Taufik Akbar Representative of Bank Indonesia Banda Aceh:

"For the initial stage, we have carried out socialization to the Community and Banking Employees by filling out a survey through a questionnaire that was distributed and also each bank has been instructed to hold training on the Socialization of Qanun Number 11 of 2019 regarding this Islamic Financial Institution. It is hoped that banks will know and move together to achieve the goals of the Qanun." (Interview, 22 May 2020).

\section{Socialization at Bank Negara Indonesia (BNI)}

For the socialization of conventional banking in Lhokseumawe City, they held training for employees of each bank to participate in the socialization of Qanun Number 11 of 2018 concerning Islamic Financial Institutions and customers also filled out a website survey whose scope was an area of Lhokseumawe City. Conventional banking employees also began to learn how to 
do Islamic banking as conveyed by Mr. Vicky Zulfikar as the head of Conventional Banking BNI Lhokseumawe who said:

"Conversion of state-owned conventional banking to Islamic banking is not an easy thing and it is done gradually. Like where the earth is stepped on, the sky is held up, we are ready to follow the regional Qanun that applies in our place. For its preparation, we will prepare internally and externally for the implementation of Qanun Number 11 of 2018 concerning Islamic Financial Institutions ". (Interview, July 15, 2020).

\section{Socialization at the State Savings Bank (BTN)}

Bank BTN through the sub-branches of Lhokseumawe City moves faster than other banks, as stated by Mr. Sugianto, the deputy head of the Conventional State Savings Bank of Lhokseumawe City.:

"The Lhokseumawe City State Savings Bank is a Sub-branch Office in terms of Qanun Number 11 of 2018 concerning Islamic Financial Institutions, we officially launched Sharia last February. And for the conversion of our savings, we have reached the target of 70 percent Conversion to Sharia". (Interview, 28 July 2020).

The implementation strategy carried out by the State Savings Bank is that with a different initial step from other banks, they first launch themselves that they have become BTN Syariah. For them, the trick of introducing the new image to the public first will make people move to convert their accounts to Sharia. Teuku Ighfar Hajar as PIC of BTN Syarian Banda Aceh said::

"We are also conducting socialization to employees and customers regarding the existence of this Qanun for Islamic financial institutions in Aceh. Where the earth is stepped on there the sky is upheld so we must follow the rules that exist in our area. Socialization for employees is held regularly at every morning briefing to discuss this qanun”. (interview July 28, 2020).

Before converting the account to Sharia, BTN gives its customers the option to continue to choose Conventional or Sharia with a statement from the customer in question. And for the account concerned with credit or savings, they use the method of informing all customers with SMS Blast chain messages from the State Savings Bank to immediately convert the account to Sharia so that they can still enjoy services and transact in Aceh.

\section{Socialization at Bank Rakyat Indonesia (BRI)}

Bank Rakyat Indonesia Lhokseumawe branch has 1 branch office and 16 (sixteen) units under the Lhokseumawe branch office. In the implementation of 
IHTIYATH Jurnal Manajemen Keuangan Syariah

Vol. 5 No. 2, Desember 2021

Qanun Number 11 of 2018 concerning Islamic Financial Institutions, Conventional BRI, which has a different work system from BRI Syariah, has a fast movement in terms of converting accounts. Bank Rakyat Indonesia has a different strategy used in Qanun Number 11 of 2018 concerning Islamic Financial Institutions, Ferdian Handoko as the Chairperson of BRI Kc Lhokseumawe said:

"Regarding Qanun Number 11 of 2018 concerning Islamic Financial Institutions, we have been moving since the beginning of 2019 with the initial step of providing education and training to employees, in fact we have scheduled it every year, but we prioritize the issue of accelerating conversions. Since 2019, BRI has converted more than 20,000 accounts. And we are targeting the conversion of these accounts until the end of July 2020." (Interview, August 4, 2020).

\section{Stage 2 Training}

Training for conventional banking employees is also carried out to learn how the Islamic banking system is for internal and external readiness in terms of services and services to customers. This socialization aims to make employees understand in advance the urgency of the interests of the existence of the Qanun. After the employees understand what to eat in the future, we know what to do. Both in terms of transaction services and in terms of other financing. This socialization has been held several times in 2019 before the COVID-19 pandemic, socialization was carried out face-to-face and some was carried out virtually.

\section{Training at Bank Negara Indonesia (BNI)}

Basically, a subsidiary of Bank Negara Indonesia Syariah (BNIS) uses the same application as its parent Bank Negara Indonesia (BNI) Conventional, but in certain aspects there are differences. For example in terms of financing and also in terms of transactions. To overcome this, we have also held training for employees to learn how the sharia system works which is much different from conventional, added by Mr. Vicky Zulfikar:

"Because this Qanun applies in the Aceh area, all BNI operating in Aceh have prepared for this. BNI employees who are in Aceh we take part in the Basic Sharia Banking Training (PDPS). What was done at several BNI points in Aceh, namely Banda Aceh, Lhokseumawe and Langsa. This training is a way for the employees in charge to understand the Sharia banking work system." (interview, 15 July 2020). 
Education and training has become a necessity and a right to be enjoyed for every employee in order to develop his expertise in carrying out a task or activity. In an increasingly advanced era, employees are required to be able to innovate in carrying out their duties efficiently and effectively, if education and training are not provided to employees, it is predictable that the performance of employees will not run optimally as desired. Basic Sharia Banking Training (PDPS) is very necessary for employees because switching the system from Conventional to Sharia is very different in order to facilitate the implementation of Qanun Number 11 of 2018 concerning Islamic Financial Institutions. The training provided in this case is in the form of workshops and also education for employees on duty to sharia, Linda Octaviani as Acting Leader of BNI Syariah KCP Panton Labu explained:

"The sharia training and workshops provided are very important in order to accelerate the implementation of the qanun, besides this human resource training supports the conversion of conventional banks to sharia". (interview 15 July 2020).

The training is provided to improve the quality of existing resources so that they can work more productively and also to accelerate the implementation of these qanuns in conventional banking.

\section{Training at the State Savings Bank (BTN)}

Another alternative that the State Savings Bank does in implementing the Qanun is by providing training to employees assigned to BTN Syariah, Teuku Ighfar added:

"In the process of switching to Sharia, we have provided training to our employees assigned to Sharia with the Basic Sharia Banking Training (PDPS) twice at the beginning of 2020. Actually, there were several times, but because of this pandemic, not all of them were given training, only those who were assigned. This training is very necessary for employees because the system is much different between conventional BTN and Sharia BTN." (interview 28 July 2020).

In this case, the State Savings Bank (BTN) has held training for its employees 3 times, due to this pandemic, further training will be held virtually and only in zoom meetings. Initially, the training was given only to employees on duty to sharia because they would be in direct contact with the sharia system. $\mathrm{Mr}$ Sulaiman also added: 
"In this case there is no special recruitment for employees to sharia, but employees from conventional are assisted in assigning to sharia. And also no termination of employment for employees who go to sharia because in terms of our staffing, the State Savings Bank is still in one line even though the system is different." (interview 28 July 2020).

Every State-Owned Enterprise (BUMN) Conventional banking in Lhokseumawe City plays an important role in the community's economy and also in providing financial services to the community. The existence of Qanun Number 11 of 2018 concerning Islamic Financial Institutions is a new breakthrough in the economic principles of society.

\section{Stage 3 Implementation}

Conversion of Conventional to Sharia Accounts at Bank Negara Indonesia (BNI)

In this case, BNI Banking, which includes SOEs in Lhokseumawe City, has prepared a strategy for the Implementation of Qanun Number 11 of 2018 concerning Islamic Financial Institutions, each bank is different Mr. Vicky Zulfikar as Chairman of Bank Negara Indonesia Lhokseumawe said:

"Bank Negara Indonesia in implementing Qanun Number 11 of 2018 concerning Islamic Financial Institutions has prepared 4 phases, the first phase is socialization to employees and customers, the second phase provides Sharia training to employees and calculates and makes asset transfers, the third converts customer savings from conventional to sharia gradually and fourthly, implementing Qanun Number 11 of 2018 concerning Islamic Financial Institutions in all outlets in Lhokseumawe. However, this is not easy because in every phase there are gaps found in their expectations". (Interview, 15 July 2020)

Bank Negara Indonesia Kcu Lhokseumawe in early 2020 was already engaged in implementing the Qanun, the installation of BNI Syariah pamphlets in 5 Sub-Branch Offices (KCP) has been carried out since 2019. Although it is still running a dual banking system in one outlet, meaning that sharia transaction services can be accessed do it at conventional BNI but only at the beginning of May 2020 for customer service and opening an account it can be done at the subbranch office.

In an effort to accelerate the migration of conventional accounts to sharia, BNI sales and frontliners have already made calls and also SMS conventional customers to immediately transfer their accounts. Every customer who transacts at the Teller is also given information to immediately migrate sharia accounts until the end of October. Mr. Vicky Zulfikar says: 
"We assign both sales and frontliner employees to finish their work in the afternoon, sending messages or calling customers and following up on customers managed by each sales in an effort to provide information for converting accounts to sharia. And also for now, we don't allow conventional account openings anymore, but for opening new accounts directly to BNI Syariah accounts. And every customer who transacts at our teller or customer service immediately directs them to immediately convert to a sharia account. This is one of the alternatives that we do for acceleration." (interview 10 July 2020).

Conversion of Conventional to Sharia Accounts at the State Savings Bank (BTN)

The State Savings Bank (BTN) also converts conventional le syraiah accounts in stages. Since the beginning of 2020, the State Savings Bank has started picking up the ball to priority and core customers first for converting accounts to sharia. As well as customers who have payroll and also cooperate with the State Savings Bank. Mr. Sulaiman explained:

"In terms of account conversion, we prioritize priority customers who have funds for us to convert to sharia accounts first. This is in order to accelerate the conversion target to syriah and to achieve branch Third Party Funds (DPK). After that, customers who have payroll and collaboration with our BTN are not collective accounts" (interview 28 July 2020).

In addition, the sub-branches that have been sharia since the beginning of 2020 have not opened conventional accounts and financing to customers has also been carried out in a sharia manner. Teuku Ighfar Hajar as PIC of BTN Syarian Banda Aceh said::

"Since May 2020, we have switched to Sharia for Conventional services no longer exist. For every customer who comes to open an account, we immediately open a Sharia account. However, if there are customers who don't want to switch to Sharia, we ask the customer concerned to make a statement if there are problems that are no longer served in Aceh but must go to BTN Medan."(interview 28 July 2020).

\section{Conversion of Conventional to Sharia Accounts at Bank Rakyat Indonesia (BRI)}

Our conventional BRI customers contact us directly to convert their accounts to BRI Syariah and also every customer who comes to our customer service immediately changes their account. In terms of implementing this Qanun, we prioritize account conversion targets from conventional to Sharia, Ferdian Handoko added:

"Avoiding customer service queues that are too crowded on normal weekdays, we overtime our employees and prepare special services for converting accounts to Sharia on Saturdays for 3 months since the beginning of last April. 
IHTIYATH Jurnal Manajemen Keuangan Syariah

Vol. 5 No. 2, Desember 2021

We do this to accelerate Conversion. We are targeting early 2021 Conventional BRI services in Lhokseumawe have officially changed to Sharia." (interview, 4 Aug 2020).

The implementation of this Qanun is not easy because changing an existing system to a new system takes a long time. But we are trying to follow the rules that apply in Aceh, Ferdian Handoko also added:

"For salary accounts, social assistance and also student scholarship accounts, we migrated to Sharia by opening a collective account (Burekol) to make it easier and as of last August all those whose salaries were paid in the new BRI Syariah account can be used." (interview 04 August 2020).

After switching accounts to BRI Syariah Conventional customers can already enjoy BRI Syariah services, but at first it will feel different because the system is different. We hope that customers will be familiar with BRI Syariah services.

\section{Conversion of Conventional to Sharia Accounts at Bank Mandiri}

Bank Mandiri and Bank Syariah Mandiri have different systems and different capital. In terms of implementing this Qanun, we are still running a dual banking system, namely conventional and Islamic services under one banking roof. Bank Mandiri in terms of the strategy for implementing Qanun Number 11 of 2018 concerning Islamic Financial Institutions Afnal Gunawan as Operational Management of Bank Mandiri in Lhokseumawe City said:

"Currently we are still running a dual banking system and are in the stage of switching accounts from conventional to sharia. Because the conventional Bank Mandiri system is a bit different, we are late in converting. However, in 2020 we have targeted to implement Qanun No. 11 of 2018 concerning Islamic Financial Institutions 100\%, God willing. " (Interview, 10 August 2020).

Bank Mandiri in terms of converting an account to BSM by picking up the ball, namely calling the customer and also sending information messages to convert the account if it has not been converted to sharia, the bank will block the customer's atm card, as said by Afnal Gunawan:

"We have notified customers to switch Conventional accounts to Sharia with a limit until November 2020. After that Conventional services are no longer served. And we temporarily block customer's ATM cards that have not yet transferred their accounts to Sharia in order to speed up the conversion process." (interview, 10 August 2020).

For employees who are currently serving in Sharia are still from Bank Syariah Mandiri and there are also some from Conventional in the Decree 
assigned to Sharia, employees who are assigned to Sharia have been given training in Sharia banking. And for the current employment status, we still provide options for employees, this was explained directly by Mr. Afnal Gunawan:

"For the employees themselves, in implementing this Qanun, we provide two conventional or Sharia options. If the employee chooses Sharia, the employee will later be assigned to sharia and still in the Aceh area. However, if the employee chooses to stay in Conventional then later on, the employee will be transferred outside Aceh." (interview, 10 August 2020).

Binding rules such as Qanun and Perda are very important in implementing and developing a policy because they provide a clearer path for banks in Lhokseumawe City to implement and develop Qanun Number 11 of 2018 concerning Islamic Financial Institutions. Islamic banking, both in terms of strategy for developing Islamic banking products, strategies for managing human resources, and other operational strategies, must be more optimal in directing its strategic plans for future industrial development. Because Indonesia is the largest Muslim-majority country in the world, it has the potential to develop Islamic finance in this era of globalization.

From the statement above, we can observe that the Lhokseumawe City Banking implementing apparatus is not ready and has problems in executing Qanun Number 11 of 2018 concerning Islamic Financial Institutions. There is a desire for large-scale Islamic banks, which is in line with the second policy objective of strengthening the capital and commercial scale of Islamic banks. There are many alternatives to accelerate the development of Islamic banking in order to build large-scale Islamic banks, including (a) conversion, (b) mergers, (c) holding, and (d) establishment of new Islamic banks. This initiative is projected to bring Islamic banks to Indonesia on a large scale, enabling them to develop rapidly and sustainably, especially in funding large government and private sector projects.

\section{Customer Feedback}

At the beginning of 2019, the issue of bank transition or bank conversion had begun to intensify in the community. The response from the community is also there are those who support and there are those who refuse. On one occasion, a customer who is a teacher who often conducts transactions at BNI regarding the 
IHTIYATH Jurnal Manajemen Keuangan Syariah

Vol. 5 No. 2, Desember 2021

distribution of PIP Scholarships responded to the Bank's shift to Sharia. Ustad Junaidi added:

"Before switching to Sharia, it is better for us to make our hearts and intentions clear first to switch to Sharia. This means that in the first sharia the employees are the new institutions. Because if we sincerely emigrate to Sharia, God willing, the way will be made easy." (interview, August 13, 2020).

One of the customers who use Irna's banking services as a customer of Bank Negara Indonesia said:

"Seeing the conversion of conventional banking to Sharia is like two different sides of a coin. As a conventional bank user, I feel comfortable with conventional banking and it's easier, so I'm reluctant to switch to Islamic banking." (Interview, June 4, 2020).

Some of the people who responded to Qanun 11 of 2018 regarding Islamic Financial Institutions agreed and some did not. The thing that makes them reluctant to switch is because they are comfortable with the services of one bank and also according to them it is easier to use conventional banking services. Every new policy must reap the pros and cons of the community. However, this will later become a consideration for banking service providers to inform the public and change the public's mindset about Islamic Banking.

\section{Internal Barriers to the Implementation of Qanun Number 11 of 2018 concerning Islamic Financial Institutions in BUMN Conventional Banking in Lhokseumawe City}

Internal restrictions are factors or circumstances that arise from within the organization's environment and limit, hinder, or prohibit the achievement of a goal. Internal obstacles to the implementation of Qanun 11 of 2018 concerning Islamic Financial Institutions include:

1. Network and technology affordability is still an uneven and inefficient issue.

Office channeling, where conventional banks with sharia business units open sharia service counters at their regular branches, is one solution to overcome this problem. Customers who want to create an account with a sharia business unit must visit a sharia branch before a bank that has a sharia business unit can serve it. With this office channeling, they are no 
longer required to come to sharia branches but can be served at conventional branches that have sharia service counters. In addition to ATM problems that often appear in the field, the entire ATM network belonging to conventional banks is also often encountered with transactions, both cash and non-cash.

2. Inadequate marketing and promotion

Promotions carried out by Islamic banking are not good enough, so there are still many people who do not understand how to get Islamic banking services. The lack of marketing budget causes the lack of promotion carried out by Islamic banks which is the biggest obstacle in carrying out promotions in Islamic banks. Meanwhile, the promotion budget for conventional banks is bigger than Islamic banks, so the echo of Islamic banking is still inferior to conventional banking. The ease of public access to Islamic financial services will not be optimal without adequate advertising. Islamic banks must be able to formulate an efficient promotion plan so that the general public is aware of the various Islamic banking products available. Therefore, Indonesian Islamic Banking must be more active in developing its business, both in terms of socialization and innovation of bank instruments and products, as well as providing satisfactory services and operationalizing Islamic banks not only as financial and commercial institutions, but also as social financial institutions, because of their involvement Islamic banks in social activities will generate positive sentiments in various ways.

3. Inadequate human resources.

It is as if Islamic banks are preoccupied with the language of "how to Islamize our financial system" and ignore the discourse of "how to Islamize banking people". Many problems in Islamic banks are caused by the lack of understanding and awareness of Islamic bank practitioners on the basics of Islamic economics (Islamic banking). Currently, Islamic banks require human resources who are fluent in the fiqh component of Islamic banking as well as practical banking management. Furthermore, Islamic banks must provide regular training to their employees so that their knowledge of Islamic banking always increases. This is an attempt 
not only to "Islamicize the banking system", but also to "Islamicize the financial system".

\section{CONCLUSION}

Conversion of State-Owned Enterprises (BUMN) is a much discussed option and will have a significant impact, but will be difficult to implement in the next three years. Bank Negara Indonesia, Bank Rakyat Indonesia, Bank Mandiri, and Bank Tabungan Negara are four banks that are classified as State-Owned Enterprises (BUMN). Islamic banks in general have enormous potential and opportunities. Islamic banks have also proven to be an ideal bank model to encourage the country's economic progress in terms of asset growth.

The implementation of Qanun number 11 of 2018 did not go well; many obstacles encountered in the field, both internal and external constraints. The industry's internal barriers include: the lack of coverage of Islamic banking technology and system, the lack of socialization of the qanun of Islamic financial institutions, and the large number of consumers who will convert their accounts to sharia but will be served due to a lack of bank officers.

Meanwhile, the large number of customers who do not want to convert their accounts to sharia because they are satisfied with conventional banks, as well as the lack of public trust in Islamic banks, are external obstacles found in the field. However, Islamic banks must catch up with regular banks that were formed earlier in terms of service quality. In addition, special banking regulations are needed for Islamic Banking so that they can carry out their duties without having to follow the conventional system, thus creating productive competition between Islamic and conventional banks. There are several strategies used in Lhokseumawe City to implement Qanun number 11 of 2018 concerning Islamic Financial Institutions in 4 (four) traditional State-Owned Enterprises (BUMN) banks, namely:

a. Socialization, namely introducing and inviting the public to switch from conventional to sharia by calling and sending SMS blasts.

b. Basic Sharia Banking Training (PDPS), which will provide all employees with briefing and training on how to use the sharia banking system. 
c. Account conversion from conventional to sharia: Account conversion from conventional to sharia has been completed by nearly $75 \%$ of banks, and this process will continue until early 2021.

\section{REFERENCE}

Abadi, R. (2015). Sejarah dan Perkembangan Bank Syariah Di Indonesia. Dipetik 10 03, 2015, dari Cermati: http://www.cermati.com/artikel/sejar ah-dan-perkembangan-bank-syariah- di-indonesia.

Analisis Perbandingan Kinerja Keuangan Bank Konvensional dan Bank Syariah. (2010). 1-3.

Choir. (2010, 03 31). Kelebihan dan Kendala Bank Syariah. Dipetik 10 03, 2015, Dari Zona Ekonomi islam: http://zonaekis.com/kelebihan-dan-kendalabank-syariah/

Dharma, Surya. 2009. Manajemen Kinerja Falsafah Teori dan Penerapannya. Yogyakarta: Pustaka Pelajar.

Dunn, William N. (2003). Analisis Kebijakan Publik. Yogyakarta: Gadjah Mada University Press.

Griffin, Jill. 2002. Customer Loyalty. Jakarta: Erlangga.

Hirsanuddin. (2008). Hukum Perbankan Syariah di Indonesia, Pembiayaan Bisnis dengan Konsep Kemitraan. Yoyakarta: Genta Press.

Islamy, Irfan. (2004). Prinsip-Prisip Perumusan Kebijaksanaan Negara. Jakarta: Bumi Aksara.

Iskandar. (2009). Metode Penelitian Kualitatif. Jakarta : Gaung Persada Press.

Ismail. 2013. Perbankan syariah. Jakarta: Kencana.

Mursito, I. (2014,). Keunggulan Sistem Perbankan Syaria Perbandingan dengan Sistem Konvensional.

Kompasia: http://www.kompasiana.com/ianmurs ito/keunggulan-sistemperbankan-syariah-perbandingan-dengan-sistem-

konvensional_54f3cdd4745513902b6c7f39 di Indonesia. Jurnal Ekonomi, 347-357.

Ridwan, A. H. (2013). Manajemen Baitul Mal wa Tamwil. Bandung: Pustaka Setia.

Sugiyono. (2017). Metode Penelitian Kuantitatif, Kualitatif, dan R\&D. Bandung : Alfabeta. 
IHTIYATH Jurnal Manajemen Keuangan Syariah

Vol. 5 No. 2, Desember 2021

Qanun Aceh Nomor 11 Tahun 2018 Tentang Lembaga Keuangan Syariah

PBI No. 11/3/PBI/2009 tentang Bank Umum Syariah

PBI No. 11/1/PBI/2009 tentang Bank Umum

http://www.bi.go.id

https://www.cermati.com/artikel/sejarah-dan-perkembangan-bank-syariah-diindonesia

http://portalhiuinjakarta.blogspot.co.id/2009/03/bank-konvensional-vs-banksyariah.html

http://dhayattoni80.blogspot.co.id/2013/05/perkembangan-bank-syariah-diindonesia.html

https://eriellg.wordpress.com/2016/05/22/persaingan-bank-syariah-dan-bankkonvensional/ 